\section{Rapid increase in heated tobacco product (HTP) use from 2015 to 2019: from the Japan 'Society and New Tobacco' Internet Survey (JASTIS)}

Heated tobacco products (HTPs) were introduced in Japan in 2014 without sufficient scientific evidence about the associated health risks. Our previous report found substantial HTP use in Japan after 2016. ${ }^{1}$ This study aims to clarify how the prevalence of HTP use (IQOS, Ploom TECH and glo) has increased over the last 5 years in Japan using ongoing retrospective Japan 'Society and New Tobacco' Internet Survey (JASTIS) data.

\section{METHOD}

We calculated the prevalence of HTP use from 2015 to 2019 from the JASTIS dataset. At baseline in 2015, 8240 participants aged 15-69 years were randomly selected from a Japanese large internet search agency, Rakuten Research. ${ }^{2}$ Adjusted estimates using inverse probability weighting (IPW) obtained from a propensity score (calculated by logistic regression models using basic demographic and socioeconomic factors) were calculated to correct for the selectivity of internet-based samples, using a probability sample that is representative of the Japanese population from the Comprehensive
Survey of Living Conditions of People on Health and Welfare. ${ }^{3}$ We further adjusted for non-response using IPW from the 2016 survey or after. Detailed methods are available elsewhere. ${ }^{4}$

\section{RESULTS}

HTP use in Japan increased from 0.2\% in 2015 to $11.3 \%$ in 2019 , as estimated among participants aged 15-69 years (table 1). In 2019, HTP use prevalence was over $30 \%$ among current smokers with or without intention to quit $30.8 \%$ and $43.2 \%$, respectively). HTP use prevalence was more than $10 \%$ higher among men, participants in their 20s and 30s than other categories.

According to product type, the most recent 2019 HTP use prevalence (95\% CI) in Japan was estimated as follows: $5.8 \% \quad(4.4 \%-7.6 \%)$ for IQOS, $6.1 \%$ (4.7\%-7.8\%) for Ploom TECH and 3.6\% $(2.6 \%-5.0 \%)$ for glo (online supplementary table 1$)$.

\section{DISCUSSION}

HTP use prevalence as estimated in the JASTIS study was $11.3 \%$ among the entire Japanese population and over 30\% among baseline current cigarette smokers in 2019. Our 2017 report showed baseline current smokers with intention to quit were more likely to use HTPs. ${ }^{1}$ However, the updated estimate found use of HTPs had rapidly extended to current smokers, regardless of their intention to quit. The widespread availability of HTPs in Japan may encourage smokers of cigarettes to replace them with HTPs.

The widespread use of HTPs makes it difficult to create public health policies for a tobacco-free society. Following the revised Health Promotion Law, ${ }^{5}$ use of HTPs is allowed in specially designated rooms in restaurants where customers will also be able to eat and drink, from April 2020. Under the new law, the tobacco industry promotes HTPs on websites, in official stores, consumer electronics retailers and convenience stores. ${ }^{6} 7$ However, WHO advises policy-makers to ban HTP marketing and provide warning messages about HTPs as well as conventional cigarettes. ${ }^{8}$

Our study highlights the rapid spread of HTPs in Japan, especially among smokers, men and the younger population. The world highest prevalence of HTP use in Japan should be carefully monitored as it can forewarn other countries about the spread of HTPs.

\section{Ai Hori $\odot,{ }^{1}$ Takahiro Tabuchi, ${ }^{2}$ Naoki Kunugita ${ }^{3}$ \\ 'Department of Global Public Health, University of Tsukuba, Tsukuba, Ibaraki, Japan \\ ${ }^{2}$ Cancer Control Center, Osaka Medical Center for Cancer and Cardiovascular Diseases, Osaka, Japan ${ }^{3}$ University of Occupational and Environmental Health Japan, Kitakyushu, Fukuoka, Japan}

Correspondence to Dr Ai Hori, Department of Global Public Health, University of Tsukuba, Tsukuba, Ibaraki 305-8577, Japan; ihori-sgy@umin.ac.jp

Acknowledgements We would like to thank Dr Julia Mortimer for English language editing.

Table 1 Adjusted prevalence of current heated tobacco (HTP) use (use in previous 30 days) from 2015 to 2019 in Japan

\begin{tabular}{|c|c|c|c|c|c|c|c|c|c|c|c|c|}
\hline \multirow{2}{*}{$\begin{array}{l}\text { Characteristics at } \\
2015 \text { baseline }\end{array}$} & \multirow[b]{2}{*}{$\mathbf{n}$} & \multirow[b]{2}{*}{$\%$} & \multicolumn{10}{|c|}{ Adjusted number and percentage $(95 \% \mathrm{Cl})$ of HTP use } \\
\hline & & & 2015 & & $2016 t$ & & 2017 & & 2018 & & 2019 & \\
\hline Total & 8240 & 100 & 13.5 & 0.2 (NC) & 62.0 & $0.8(0.4$ to 0.1$)$ & 301.5 & 3.7 ( 2.8 to 4.8$)$ & 661.1 & $8.0(6.5$ to 9.8$)$ & 928.8 & $11.3(9.3$ to 13.6$)$ \\
\hline \multicolumn{13}{|l|}{ Gender } \\
\hline Men & 4084 & 49.6 & 12.5 & 0.3 (NC) & 48.6 & $1.2(0.6$ to 2.3$)$ & 225.1 & 5.6 (4.0 to 7.8$)$ & 497.5 & $12.3(9.7$ to 15.5$)$ & 694.2 & $17.2(14.0$ to 21.1$)$ \\
\hline Women & 4156 & 50.4 & 1.0 & 0 (NC) & 13.4 & 0.3 (0.1 to 0.8$)$ & 76.4 & $1.8(0.1$ to 3.1$)$ & 163.6 & 3.9 (2.7 to 5.7$)$ & 234.6 & 5.6 (3.8 to 8.2 ) \\
\hline \multicolumn{13}{|l|}{ Age (years) } \\
\hline $15-19$ & 881 & 10.7 & 4.9 & $0.6(\mathrm{NC})$ & 13.2 & $2.0(0.3$ to 12.1$)$ & 8.4 & $1.4(0.4$ to 5.5$)$ & 38.5 & 7.4 (2.7 to 18.7$)$ & 18.3 & 4.8 (1.7 to 12.4$)$ \\
\hline $20-29$ & 1462 & 17.7 & 3.5 & 0.2 (NC) & 16.3 & 1.0 (0.5 to 2.2 ) & 86.4 & $5.7(3.2$ to 10.0$)$ & 210.5 & 14.1 (9.1 to 20.8 ) & 266.3 & 17.0 (11.3 to 24.7$)$ \\
\hline $30-39$ & 1465 & 17.8 & 4.3 & 0.3 (NC) & 19.2 & 1.2 (0.5 to 2.7$)$ & 87.7 & 5.1 (3.1 to 8.4 ) & 152.3 & 9.0 (5.9 to 12.5$)$ & 254.7 & 15.2 (10.4 to 21.6$)$ \\
\hline $40-49$ & 1487 & 18.1 & 0 & 0 (NC) & 6.3 & $0.4(0.1$ to 1.5$)$ & 61.8 & 4.0 (2.1 to 7.4$)$ & 132.9 & 8.5 (5.7 to 12.5$)$ & 211.3 & 12.5 (8.8 to 17.5$)$ \\
\hline $50-59$ & 1461 & 17.7 & 0.5 & 0 (NC) & 6.2 & 0.5 (0.1 to 2.0$)$ & 49.0 & 3.5 (1.9 to 6.6 ) & 95.2 & 6.8 (4.5 to 10.2$)$ & 129.1 & 9.1 (6.0 to 13.7) \\
\hline $60-69$ & 1484 & 18.0 & 0.3 & 0 (NC) & 0.8 & 0.1 (0 to 2.3 ) & 8.4 & 0.6 (0.1 to 3.4$)$ & 31.6 & $2.0(0.9$ to 4.6$)$ & 49.1 & 3.3 (1.8 to 6.0$)$ \\
\hline \multicolumn{13}{|l|}{$\begin{array}{l}\text { Cigarette smoking } \\
\text { status }\end{array}$} \\
\hline Never smoker & 4941 & 60.0 & 0.2 & 0 (NC) & 13.2 & 0.3 (0.1 to 0.7$)$ & 65.2 & 1.3 (0.9 to 2.1$)$ & 132.4 & 2.7 (1.8 to 4.2$)$ & 129.5 & 2.7 (1.7 to 4.2$)$ \\
\hline Former smoker & 1608 & 19.5 & 4.8 & 0.3 (NC) & 29.1 & $1.8(0.7$ to 4.6$)$ & 35.1 & 2.1 (0.9 to 4.5$)$ & 67.5 & 4.0 (2.2 to 7.2$)$ & 59.2 & 3.7 (1.8 to 7.3 ) \\
\hline $\begin{array}{l}\text { Smoker with } \\
\text { intention to quit }\end{array}$ & 279 & 3.4 & 1.6 & $0.6(\mathrm{NC})$ & 2.4 & 1.1 (0.3 to 4.2 ) & 45.1 & 18.4 (8.4 to 35.8$)$ & 55.4 & $22.0(11.4$ to 38.3$)$ & 64.0 & $30.8(16.0$ to 51.0$)$ \\
\hline $\begin{array}{l}\text { Smoker without } \\
\text { intention to quit }\end{array}$ & 1412 & 17.1 & 6.9 & 0.5 (NC) & 17.3 & $1.2(0.5$ to 0.3$)$ & 156 & 11.0 (7.3 to 16.2$)$ & 405.8 & 27.5 (21.4 to 34.6$)$ & 676.1 & 43.2 (35.7 to 51.0$)$ \\
\hline
\end{tabular}


Contributors TT had full access to all of the data in the study and takes responsibility for the integrity of the data and the accuracy of the data analysis.Study concept and design: all authors; acquisition of data: TT; analysis and interpretation of data: AH and TT: drafting of the manuscript: $\mathrm{AH}$ and $\mathrm{TT}$; critical revision of the manuscript for important intellectual content: all authors; statistical analysis: AH and TT; and study supervision: NK.

Funding This work was supported by Health and Labour Sciences Research Grants (H26-junkankitouippan-023 and H29-tokubetsu-shitei-006) and Japan Society for the Promotion of Science (JSPS) KAKENHI Grants (JP18H03062).

Competing interests None declared.

Patient consent for publication Not required.

Ethics approval Ethics approval was obtained from the Research Ethics Committee of the Osaka International Cancer Institute (no.1412175183) and the National Institute of Public Health (NIPH-IBRA\#12112).

Provenance and peer review Not commissioned; externally peer reviewed.$$
\text { (2) }
$$$$
\text { OPEN ACCESS }
$$

Open access This is an open access article distributed in accordance with the Creative Commons Attribution Non Commercial (CC BY-NC 4.0) license, which permits others to distribute, remix, adapt, build upon this work non-commercially, and license their derivative works on different terms, provided the original work is properly cited, appropriate credit is given, any changes made indicated, and the use is non-commercial. See: http:// creativecommons.org/licenses/by-nc/4.0/.

(C) Author(s) (or their employer(s)) 2021. Re-use permitted under CC BY-NC. No commercial re-use. See rights and permissions. Published by BMJ.

- Additional material is published online only. To view please visit the journal online (http://dx.doi.org/10. 1136/tobaccocontrol-2020-055652).

\section{D) Check for updates}

To cite Hori A, Tabuchi T, Kunugita N. Tob Control 2021:30:474-475.

Received 22 January 2020

Revised 27 April 2020

Accepted 29 April 2020

Published Online First 5 June 2020

Tob Control 2021;30:474-475.

doi:10.1136/tobaccocontrol-2020-055652

\section{ORCID iD}

Ai Hori http://orcid.org/0000-0002-0191-5996

\section{REFERENCES}

1 Tabuchi T, Gallus S, Shinozaki T, et al. Heat-notburn tobacco product use in Japan: its prevalence, predictors and perceived symptoms from exposure to secondhand heat-not-burn tobacco aerosol. Tob Control 2018;27:e25-33.

2 Tabuchi T, Shinozaki T, Kunugita N, et al. Study Profile: The Japan "Society and New Tobacco" Internet Survey (JASTIS): A Longitudinal Internet Cohort Study of HeatNot-Burn Tobacco Products, Electronic Cigarettes, and Conventional Tobacco Products in Japan. J Epidemiol 2019;29:444-50.

3 Ministry of Health, Labour and Welfare. Comprehensive survey of living conditions of people on health and welfare, 2010. Available: https://www.mhlw.go.jp/ english/database/db-hss/cslc-report2010.html [Accessed 19 Jan 2020].

4 Tabuchi T, Kiyohara K, Hoshino T, et al. Awareness and use of electronic cigarettes and heat-not-burn tobacco products in Japan. Addiction 2016:111:706-13.

5 Ministry of Health, Labour and Welfare. Outline of the act on the partial revision of the health promotion act (NO. 78 of 2018), 2018. Available: https://www. mhlw.go.jp/english/policy/health-medical/health/dl/ 201904kenko.pdf [Accessed 18 Jan 2020].

6 Tabuchi T. The real risk of new tobacco and tobacco-like products. 1st ed. Tokyo: Naigai publishing, 2019.

7 Philip Morris Japan, 2020. Ahead of the enforcement of the revised Health Promotion Law, "Marlboro Heat Stick Bright Menthol" Launched nationwide from March 16, 2020, including convenience stores, 2020. Available: https://www.pmi.com/resources/docs/default-source/ japan-market/news/20200316_mlb_hts_bm_final.pdf? sfvrsn=9ee02db4_2 [Accessed 14 Apr 2020].

8 World health organization. Heated tobacco products (HTPs) information sheet, 2018. Available: https://apps. who.int/iris/bitstream/handle/10665/272875/WHONMH-PND-17.6-eng.pdf?ua=1 [Accessed 19 Jan 2020]. 